\title{
慢性血液透析患者の胃排泄能，小腸通過時間の検討
}

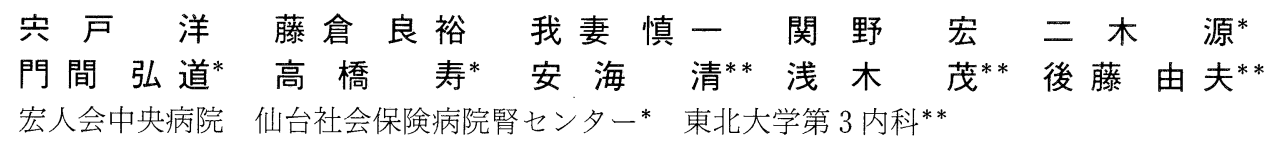

(昭和 60 年 11 月 11 日受付)

key words：血液透析患者，胃排泄能，小腸通過時間，ラクツロース，糖尿病性腎症

〈要旨〉

血液透析患者では悪心, 嘔吐, 便秘などの消化器症状がよくみられる。透析患者 23 名 (非 DM 群 11 名, DM 群 12 名）で胃排泄能を, 16 名（非 DM 群 8 名, DM 群 8 名）で小腸通過時間を測定し, 種々の検討を加えた。

胃排泄能は Heading, 原沢らのアセトアミノフェン法 45 分值を用い, アセトアミノフェン濃度は Routh らの dye

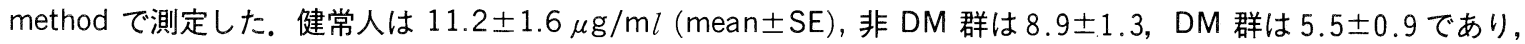
DM 群と健常人, DM 群と非 DM 群には有意差 $(\mathrm{p}<0.05)$ がみられた。 DM 群での胃排泄能の低下は糖尿病性自律 神経障害によるものと推測される。 DM 群の 8 例に対し消化管運動機能賦活剤ナパジシル酸アクラトニウム（アボビ ス $\left.{ }^{\circledR}\right)$ を服用させ, 胃排泄能の比較検討を行った. アボビス投与後は有意差 $(p<0.05)$ をもって胃排泄時間の改善 がみられ，アボビスの臨床的有用性が示唆された。 5 症例においてアセトアミノフェン法終了後に血液透析を行い, 透析前後でのアセトアミノフェン濃度を測定したところ比較的すみやかな排泄傾向がみられた。 なお検査終了後全例 において肝障害の出現はみられなかった。

小腸通過時間は Bond, 斎藤らのラクツロースを用いた呼気中水素ガス濃度の測定により判定した. 健常人が $80 \pm 10$

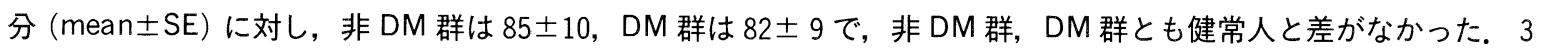
例において透析開始 1 時間後から同様の検査を行い, 血液透析の小腸通過時間への影響を検討した。 1 例は 60 分で不 変, 他の 2 例は 10 分の延長を認めた。

胃排泄能と小腸通過時間の双方を検討した例は非 DM 群 3 名, DM 群 6 名の計 9 名であったが両者には相関を認め なかった。

\section{Assessment of gastric emptying and small bowel transit time in hemodialysis patients}

Yo Shishido, M. D., Yoshihiro Fujikura, M. D., Shinichi Agatsuma, Hiroshi Sekino, M. D., Gen Futaki, M. D.*, Hiromichi Monma, M. D. *, Hisashi Takahashi, M. D.*, Kiyoshi Azumi, M. D.**, Shigeru Asaki, M. D. ${ }^{* *}$ and Yoshio Goto, M. D.**

Kojin-kai Central Hospital ; Kidney Center, Sendai Shakaihoken Hospital* ; The Third Department School of Medicine, Tohoku University**

Hemodialysis patients often complain of gastrointestinal symptoms such as nausea, vomiting and constipation.

Gastric emptying was measured in 23 hemodialysis patients (11 diabetics, 12 non-diabetics), and small bowel transit time in 16 hemodialysis patients ( 8 diabetics, 8 non-diabetics).

The method of Heading and Harasawa et al., i. e., the 45-minute value of acetaminophen, was used for estimation of gastric emptying. Acetaminophen concentration was measured according to the method of Routh et al. using the dye method. The values obtained were $11.2 \pm 1.6 \mu \mathrm{g} / \mathrm{ml}$ (mean $\pm \mathrm{SE}$ ) in normal controls, $8.9 \pm 1.3$ in non-diabetics and $5.5 \pm 0.9 \mu \mathrm{g} / \mathrm{m} l$ in diabetics. A significant difference was observed between diabetics and non

宍戸. 洋 宏人会中央病院

干 980 仙台市東七番丁 84 (022-297-6211) 
-diabetics $(p<0.05)$. The decreased gastric emptying in diabetics might be attributed to diabetic autonomic neuropathy. Aclatonium napadisilate (Abovis ${ }^{\circledR}$ ), an agent for activating digestive function, was administered to 8 diabetics in order to examine gastric emptying time. After the administration of Abovis ${ }^{\circledR}$, gastric emptying was speeded up significantly $(p<0.05)$, suggesting that Abovis ${ }^{\circledR}$ was clinically effective. Hemodialysis was performed on 5 patients following acetaminophen measurement. The acetaminophen concentration was lower after dialysis than before dialysis. None of the patients showed hepatitis after the administration of acetaminophen.

According to Bond and Saito et al., small bowel transit time measured by the concentration of pulmonary $\mathrm{H}_{2}$ exhalation with lactulose showed no difference between normal controls and non-diabetics or diabetics $[80 \pm 10$ $\min$, (mean $\pm \mathrm{SE}), 85 \pm 10 \mathrm{~min}$ and $82 \pm 9 \mathrm{~min}$, respectively].

To evaluate the effect of dialysis, small bowel transit time was measured in 3 patients 1 hour after the start of dialysis. Transit time in one patient remained unchanged at 60 minutes and in the 2 other patients it showed a delay of 10 minutes.

Both gastric emptying and small bowel transit time were measured in 3 non-diabetics and 6 diabetics, but no correlation was observed between the two measurements.

\section{緒言}

血液透析患者の消化管合併症としてはびらんや潰瘍の 発生が多く，また嘔気や嘔吐などの症状も強いことはよ く知られているところである.

我々は透析患者の胃および小腸の運動機能を検討した ので若干の考察を加えて報告する。

\section{対象・方法}

血液透析患者 39 名を対象にして胃排泄能抒よび小腸 通過時間を検討した。

1。透析患者の胃排泄能の検討

1 ）透析患者 23 名（非糖尿病患者，以下非 DM 群と 略す, 11 名. 糖尿病性腎症患者, 以下 DM 群と略す, 12 名) で胃排泄能 (gastric emptying：GE) を測定した。

非 DM 群 11 名の内訳は男性 7 名, 女性 4 名で平均年 齢は 51 歳, 透析歴は 3 力月から最長 10 年 8 力月で平均 4 年 5 力月である。

$\mathrm{DM}$ 群 12 名の内訳は男性 5 名, 女性 7 名で, 平均年齢 は 53 歳, 透析歴は 4 力月から最長 7 年 10 力月で平均 4 年 1 カ月である.

な㧍, 対象健常人は 9 名で内訳注男性 2 名, 女性 7 名 で平均年齢は 47 歳であった。

GE の測定は Heading ら ${ }^{11}$, および原沢ら ${ }^{21}$ の方法に 従った。すなわち, 早朝空腹時代試験食 Okunos A 200 $\mathrm{m} l$ に Acetaminophen (アセトアミノフェン, AAP) 1.5 $\mathrm{g}$ を混合服用させ，血中 AAP 濃度を測定することによ り算出し, 服用後 45 分の AAP 濃度をもって胃排泄能と した。

血中 AAP 濃度は Routh ら ${ }^{3)} の$ dye method で測定し た.

2 ) DM 群 8 例に扔いて消化管運動機能賦活剤ナパジ シル酸アクラトニウム(アボビス®) を服用させ, GEの
比較検討を行った。

なお，アボビス投与例 8 例のうち 3 例は試験食と同時 に, 残りの 5 例は試験食摂取 30 分前に投与した。

3 ) 透析前後の血中 AAP 濃度の変化

5 症例（非 DM 群 1 例, DM 群 4 例）で胃排泄能測 定検查終了後に血液透析を行い, 透析前後での血中 AAP 濃度を測定し，AAP の透析による影響の検討を 行った。なお， 1 例ではアボビス非服用時と服用時に測 定した。

4 ）胃排泄能と神経伝導速度との関係

20 例に扔いて尺骨神経に打ける神経伝導速度 $(\mathrm{MCV})$ を測定し, MCV 正常群と低下群に分けて, GEの比較を 行った。

2 . 透析患者の小腸通過時間の検討

1 ) 健常人と透析患者との比較

血液透析患者 16 名（非 DM 群 8 名, DM 群 8 名）で 小腸通過時間 (small bowel transit time, SBTT) を測 定し, 健常人対象 9 名と比較検討した。

非 DM 群 8 名の内訳は男性 2 名, 女性 6 名で平均年齢 は 58 歳, 透析歴は 1 力月から 7 年 8 力月, 平均 2 年 10 力 月である。

DM 群 8 名の内訳は男性 3 名, 女性 5 名で平均年齢は 54 歳, 透析歴は 4 力月から最長 6 年 6 力月, 平均 3 年 9 カ月であった。

SBTT は Bond ら ${ }^{4)}$ 抢よび斎藤ら ${ }^{5)}$ のクツロースを 用いた呼気中水素ガス濃度により測定した。すなわち流 動試験食 Okunos A $200 \mathrm{~m} l$ にラクツロース $13 \mathrm{~g}$ を加え 被験者に服用させ,試験食摂取前および摄取後 10 分間隔 で呼気採取を行い呼気中水素ガス濃度を経時的に測定 し，基礎値にくらべ十分に上昇したと考えられる時間を もって小腸通過時間とした。 


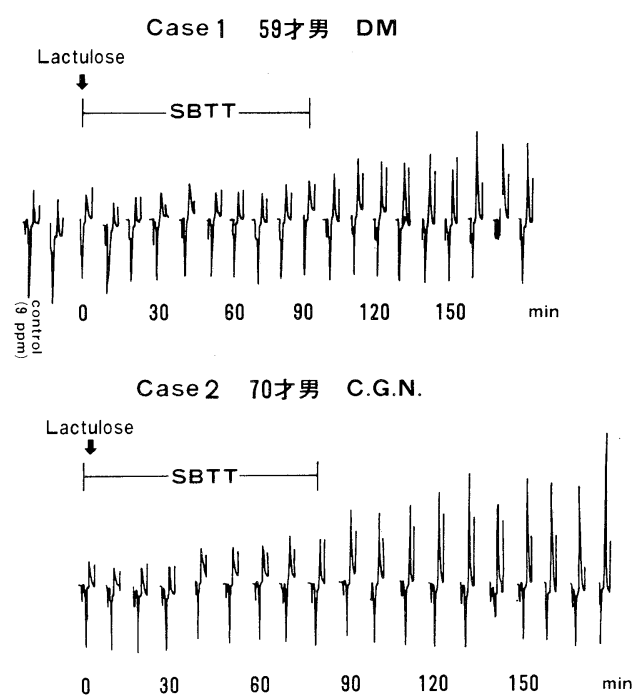

図 1 小腸通過時間 (Small bowel transit time) の測定

呼気採取にあたっては斎藤ら ${ }^{5)}$ の方活栓付きの tube を使用し, Metz ら ${ }^{6)}$ の方法に準じて終末呼気を採取し， ガスクロマトグラフィーにより終末呼気中水素ガス濃度 を測定した ${ }^{7)}$.

図 1 はラクツロース負荷後のガスクロマトグラフ上の 水素ガス濃度の経時的変化を示している。 上段では 100 分, 下段では 90 分で水素ガス濃度の増加が認められてい るので，通過時間はそれぞれ 90 分，80 分と判定した。

2 ）血液透析の小腸通過時間に与える影響

対象患者のうち 3 例において透析開始 1 時間後から同 様の検査を行い，血液透析の SBTT への影響を検討し た。

3 ．胃排泄能と小腸通過時間の相関

$\mathrm{GE}$ と SBTT の双方を検討した例は非 DM 群 3 名, DM 群 6 名の計 9 名であった。これらを対象にして両者 の相関について検討した。

なお，統計学的処理は $\mathrm{t}$ 検定を用い，5\%以下を有意 差ありとした。

\section{結果}

1. 透析患者の胃排泄能(アセトアミノフェン法 45 分 值)

健常人は $11.2 \pm 1.6$ (mean士SE) に対し, 非 DM 群

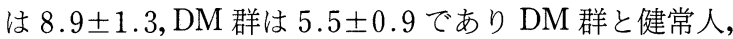
DM 群と非 DM 群には $\mathrm{p}<0.05$ で有意差がみられ DM 群では GE の低下が認められたが，非 DM 群では健常 人と有意差は認めなかった（図 2 ).

2. DM 群におけるアボビス投与による胃排泄時間の 変化

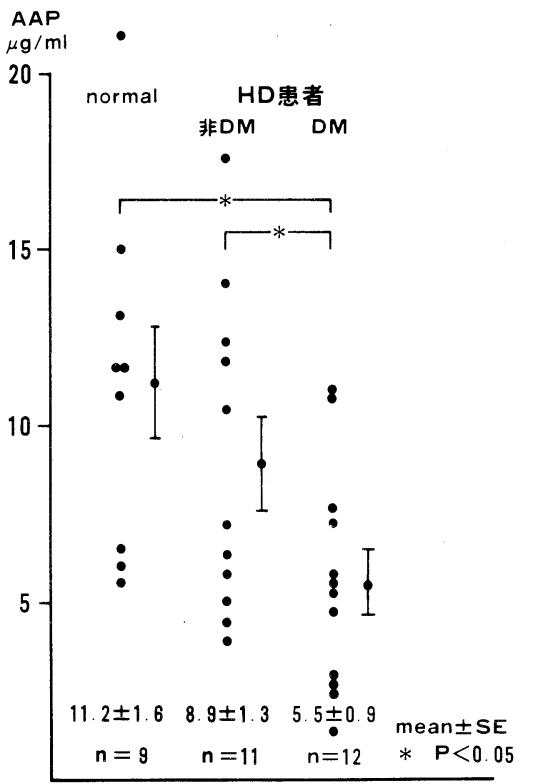

図 2 透析患者の胃排泄能（アセトアミノフェン 法 45 分値)

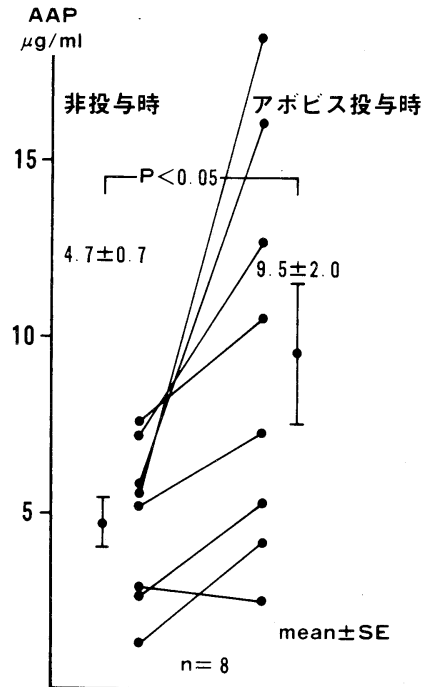

図３アア゙ビス投与による胃排泄時間の変化

アボビス投与前は $4.7 \pm 0.7 \mu \mathrm{g} / \mathrm{m} l$ (mean $\pm \mathrm{SE})$ で あったが，投与後は $9.5 \pm 2.0$ とE の改善を認めた $(\mathrm{p}<0.05)$. 特に試験食投与 30 分前にアボビスを投与 した例では著明な立進がみられた（図 3 )。

3. 血中アセトアミノフェン濃度の透析前後での変化 透析前後の AAP 濃度の変化は図 4 のようで, 比較的 すみやかな透析性が認められた。

4. 胃排泄能と神経伝導速度 
$\mathrm{MCV}$ 正常群の GE は $8.4 \pm 1.3 \mu \mathrm{g} / \mathrm{m} l$ (mea $\pm \mathrm{SE}$ ), 低 下群は $4.8 \pm 0.9$ で，両者には有意差 $(\mathrm{p}<0.05)$ が認め られた (図 5 ).

5 。透析患者の小腸通過時間

SBTT は健常人が $80 \pm 10$ 分 (mean \pm SE), 非 DM 群 は $85 \pm 10$ 分, DM 群は $82 \pm 9$ 分で, 非 DM 群, DM 群 とも健常人と差がなかった（図 6 ).

透析のSBTT への影響の検討では, 1例は不変で, 他 の 2 例では 10 分の延長が認められた（図 7 ).

6 . 胃排泄能と小腸通過時間

$\mathrm{GE}$ と SBTT の両者の検査を行った 9 例での検討で は両者には相関は認められなかった $(r=-0.564$, 図 $8)$.

\section{考按}

慢性腎不全患者においては嘔気，嘔吐，下痢などの消 化器症状がよくみられる。しかし透析療法への導入によ りその症状の改善をみる例もみられ, 特に近年の透析療 法の進歩の中で消化器症状をひきおこすとも考えられて いる尿毒症性物質 ${ }^{8)}$ の透析効率が向上したことや, 重曹 透析によりアシドーシスを速やかに改善できるように なったことで症状の出現は減少しているといえる。しか し依然として頑固な嘔気などの症状により対策に苦慮す る例も存在している。

一方, 糖尿病患者ではこれまでの報告によると糖尿病 性合併症を有しない群では胃排泄能が有意に六進してお り, gastroparesis diabeticorum では著明に低下してい

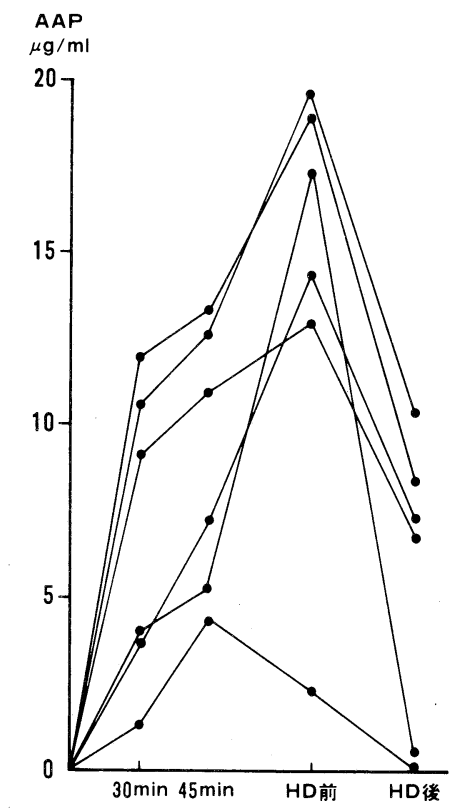

図 $4 \mathrm{AAP}$ 濃度の $\mathrm{HD}$ 前後での検討
るとされている年, 11). また, 糖尿病性腎症透析患者では 嘔気, 嘔吐, 腹部膨満などの症状が強く ${ }^{12)}$, 対策も困難な ことが多いが，これまでに糖尿病，非糖尿病にかかわら ず透析患者の消化管運動機能の検討についての報告は少 なく, Wright ら ${ }^{13)}$, McNamee ら ${ }^{14)}$ の報告があるのみ である。

Wright ${ }^{13)}$ は ${ }^{99 m} \mathrm{Tc}$ を用いたラジオアイソトープ法 により検討した結果, 透析患者における胃排泄能は正常

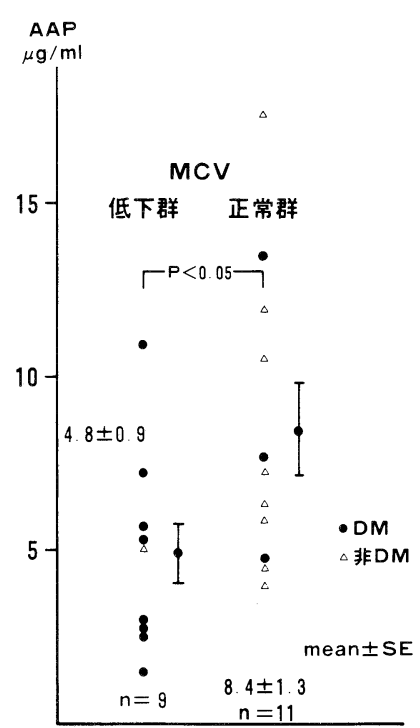

図 5 透析患者の胃排泄能と神経伝導速度 $(\mathrm{MCV})$

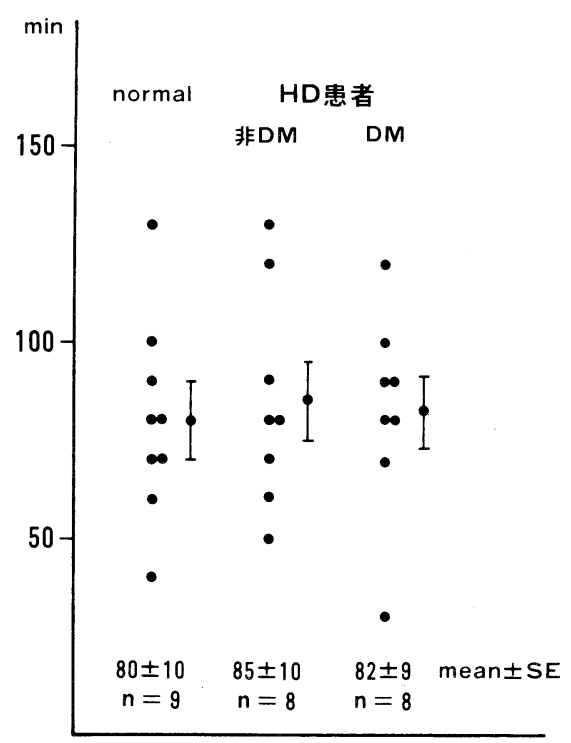

図 6 透析患者の小腸通過時間 (SBTT) 


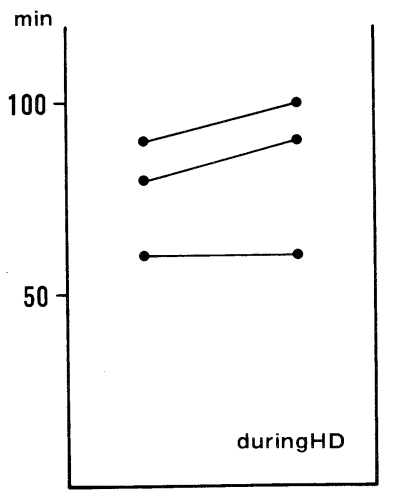

図 $7 \mathrm{HD}$ の SBTT への影響の検討（ 3 症例）

であり，消化器症状の有症状群と無症状群の間に差はみ られなかったと報告している。

また，McNamee ら ${ }^{14)}$ は透析を受けていない尿毒症患 者では胃運動に障害はあるが透析によって改善されると 報告している。

今回我々は血液透析患者を対象に糖尿病群と非糖尿病 にわけて胃排泄能を検討したが，糖尿病では胃排泄能の 著明な低下がみられたが, 非糖尿病群では健常人と差が なかった。それゆえ，非糖尿病透析患者の嘔気などの消 化器症状は運動機能の低下に原因を求めることはできな いものと判断された。

自律神経障害を有する糖尿病患者における胃排出の遅 延はドンペリドンの投与により有意に改善したとの報 告 ${ }^{11)}$ がある。

また, Wright ら ${ }^{13)}$ は透析患者の嘔気, 嘔吐に対してメ トクロプラミド製剤が効果的であったと報告している. しかし, 中枢性の消化管蠕動元進剤は長期連用の際は錐 体外路系の症状が発現するときもあるので，透析患者で は十分な注意と観察が必要である ${ }^{15)}$.

それゆえ，我々は長期連用が可能な消化管運動六進剤 としてアボビスを使用し胃排泄能の変化を検討したが, 有意な元進が認められアボビスの臨床的有用性が示唆さ れた。

アボビスは古くから漢方に用いられてきた葛根の有効 成分である Kassein R をモデルとしており，経口投与後 すみやかに消化管組織にとりこまれ，アセチルコリン受 容体に直接作用して胃・腸管の運動を促進させる ${ }^{16)}$.

高木ら ${ }^{16)}$ は投与後 $10 \sim 15$ 分から, 須山ら ${ }^{17)}$ は 30 分以 内に効果が発現すると述べているが, 検査開始前 30 分前 に投与した場合には著明な改善がえられているので，投 与方法は食前投与がよいように思われた。

AAP 法は胃での吸収がほとんどなく，腸管での吸収 がすみやかな薬物 (AAP) を服用し，一定時間後に採血

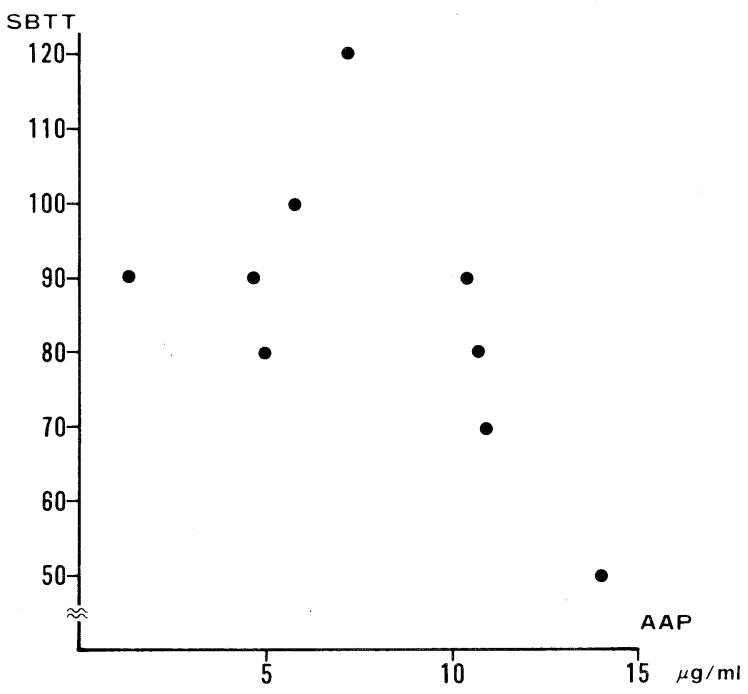

図 8 透析患者の胃排泄能と小腸通過時間

し, 血中の薬物濃度を測定し, 高い場合には胃内容の排 出元進, 低いときには排出遅延と判定する方法であり, ラジオアイソトープ法との相関も高いとされてい $ろ^{2,18)}$.

AAP はすみやかに消化管から吸収され，一部は硫酸 と, また大部分はグルクロン酸と抱合して尿中に排泄さ れるが ${ }^{19)}, 15 \mathrm{~g}$ 以上の大量服用では急性肝障害がおこる ことが知られている ${ }^{20)}$. しかし少量の服用によっても急 性肝障害をおこすこともあるので注意を要する21).

AAP の分子量は 151 であり, Farid ら ${ }^{20)}$ の検討による と AAP の透析性はクレアチニンと類似しており，透析 は血中濃度が $120 \mu \mathrm{g} / \mathrm{ml}$ 以上のときに必要となる.我々 の検討でも透析によるすみやかな除去が確認されてお り, 今回の検査に扔いて肝障害の出現や増悪例はなかつ た。しかし，透析患者においては透析当日の朝に排泄能 の検査を行うことがもっとも安全と考えられた.

村山 ${ }^{22)}$ は透析患者の小腸運動機能はすべて正常ないし 正常よりはやかったと報告している．今回の我々の検討 では DM 群, 非 DM 群とも健常人と差を認めなかった。 しかし，透析中における検討では若干の遅延が認められ た.太田ら ${ }^{23)}$ はバリウムを用い, 透析中の消化管運動を調 べ, 透析中は消化管の運動が特に妨げられていると推定 している.しかし透析そのものが消化管の運動にどのよ うな影響を与えるかはまだ不明の点もあり, 今後さらに 検討が必要と思われる。

斉藤ら ${ }^{5)}$ は自律神経障害を伴う糖尿病患者では正常者 に比し有意に上部消化管通過時間の遅延が認められたと 述べている. 


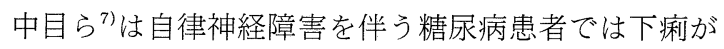
発現しているときは小腸通過時間は著明に短縮してお り, 下痢を合併していないときは遅延していると述べて いる.

しかし，今回の対象例中糖尿病者では極端なえ進や遅 延を示す例は少なかった。この理由として, 糖尿病性腎 症患者もふくめて透析患者は便秘であることが多い2 ${ }^{24)}$ とが関与しているかもしれない。

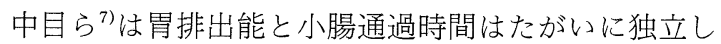
て機能をいとなんでいるのではないかと推定している が，我々の検討でも両者に相関をみなかった。

透析患者における小腸運動機能についてはこれまでの ところ，あまり検討されていないのが実情である。今回 我々の用いた方法は, 胃・小腸で吸収されないラクッロー スを経口的に投与し，ラクッロースが結腸に到着すると 常在菌により代謝されその過程で水素ガスが発生し，こ れが腸管腔を介して血中へ移行し呼気中に排泄すること から, 呼気中の水素ガスを測定することにより上部消化 管の通過時間を判定するものである。この方法は患者へ の負担がなく, 同一人での頻回の測定も容易であり ${ }^{5)}$, 再 現性も高(4).

今後さらに症例を増やして透析患者の小腸運動機能と 胃排泄能についての検討を行いたいと考えている。

\section{まとめ}

血液透析患者における胃排泄能，小腸通過時間を検討 し以下の結果をえた。

1）血液透析患者のDM 群では著明な胃排泄能の低下 が認められたが, 非 DM 群では健常人と有意差は認めな かった.

2) アボビスの使用により胃排泄能の改善がえられ臨 床的有用性が示唆された。

3）小腸通過時間の検討では非 DM 群，DM 群とも 健常人と差を認めなかったが，透析中における検討では 若干の延長を認めた。

\section{文献}

1) Heading, R. C., Nimmo, J., Prescott, L. F., Tothill, P.: The dependence of paracetamol absorption on the rate of gastric emptying. Brit. J. Pharmac., $47: 415,1973$.

2）原沢 茂, 崎田隆一, 三輪正彦, 鈴木荘太郎, 谷 礼 夫,三輪 剛 : Acetaminophen による胃排出機能検 査法。医学のあゆみ，100 (8)；632-634， 1977.

3) Routh, J. I., Shane, N. A., Arredondo, E. G., Paul, W.D. : Determination of $\mathrm{N}$-acetyl-P-aminophenol in plasma. Clinical Chemistry, $14: 882$,
1968.

4) Bond, J. H., Levitt, O. : Investgation of small bowel transit time in man utilizing pulmonary hydrogen $\left(\mathrm{H}_{2}\right)$ measurements. J. Lab. Clin. Med., $85: 546-555,1975$.

5）斉藤行世, 丸浜喜亮, 後藤由夫：呼気中水素ガスに よる上部消化管通過時間測定法. 医学のあゆみ, 117(12) ; 1011-1013， 1981.

6) Metz, G., Gassull, M. A., Leeds, A. R., Blendis, L. M., Jenkins, D. J. A. : A simple method of measuring breath hydrogen in carbohydrate malabsorption by end-expiratory sampling. Clin. Sci. Mole. Med., 50 : 237-240, 1976.

7）中目千之，赤井裕輝，本郷道夫，今井信行，豊田隆 謙, 後藤由夫, 奥口文宣, 小松寛治: 糖尿病患者に 扣ける消化管運動障害と高モチリン血症. 日本消化 器病学会誌, 79(12)；2207-2215，1982.

8）藤原誠治, 中尾俊之, 宮原正: 血清 methylguanidine 濃度と尿毒症症状との関連性について. 腎と透析，12 (6)；715-720，1982.

9）後藤由夫, 及川 登: 糖尿病患者の自律神経障害. 神経内科，19；231-238，1983。

10）後藤由夫, 及川 登: 糖尿病患者の神経障害. 臨床 と研究，60；3581-3588，1983.

11）皇良坤, 野原秋夫, 渡辺嘉久: 糖尿病と胃排出能. 上部消化管運動障害, 常岡健二, 三輪 剛, 関口利 和編．東京，文光堂， p 219，1985。

12）杉野信博: 糖尿病透析患者の合併症. 糖尿病性腎症. 杉野信博，平田幸正，繁田幸男，広瀬賢次編，東京， 医学書院. p 115, 1982.

13) Wright, R. A., Rosa, C., Ronald, W. : Gastric emptying in patients with chronic renal failure receiving hemodialysis. Arch. Intern. Med., 144 : 495-496, 1984.

14) McNamee, P. T., Collins, B. J., Moore, G. W., Doherty, C. C., McGeown, M.G. : Gastric emptying in chronic renal failure. IXth International Congress of Nephrology, p 354, 1984.

15）鈴木正司：V薬剂による精神神経症状。第VIII章 精 神神経症状と透析性脳症。透析療法に打ける合併症. 大野丞二監修，東京，日本メディカルセンター， p 145, 1981.

16）高木敬次郎, 今村雅志: Acetyllactoylcholine-1, 5 -nahathalene disulfonate (TM 723) の胃腸管に対 する作用。応用薬理，13(4)；509-512，1977.

17）須山哲次, 川村一郎, 井上正規, 三好秋馬 : Acetyl- 
lactoylcholine-1, 5-naphthalene disulfonate (TM 723）のヒト胃排出能および胃分泌能に及ぼす効果 について. 現代医療，11；1081-1092，1979.

18）原沢 茂, 谷 礼夫, 野見山哲, 崎田隆一, 三輪正 彦, 鈴木荘太郎, 三輪 剛：消化器疾患と胃排出能 第 1 報 消化性潰瘍とその再発. 日内会誌, 68 (7); 733-741, 1979.

19) Cornely, D. A., Ritter, J.A. : N-acetyl-P-aminophenol (tylenol elexir) as a pediatric antipyretic -analgesic. J. Am. Med. Assoc., 160 : 1219-1221, 1956.

20) Farid, N. R., Glynn, J. P., Kerr, D. N. S. : Haemodialysis in paracetamol self-poisoning. Lancet, 26 : 396-398, 1972.

21）安永満, 松田彰史, 村田誠, 荻野昌昭, 門 祐
二, 新開泰司, 名和田浩, 半田哲郎, 野田健一, 福 田陽平, 沖田 極, 竹本忠良: 少量のアセトアミ, フェン服用による急性肝障害の 2 例. 肝臓, 26( 4)； 493-499, 1985.

22）村山忠裕：長期透析における合併症（特に消化管） に関する臨床的研究. 鹿児島大学医学雑誌, 26(2); 635-654, 1974.

23）太田和夫：消化管の合併症, 透析患者の診かた考え 方. 太田和夫，杉野信博，春木繁一，編集，東京， 南江堂, p 65, 1979 .

24）遠藤裕子, 斉藤洋子, 新山泰子, 吉田ふみ子, 新井 せつ子, 久富恵子, 元村千佳, 西川久美子, 藤倉良 裕, 宍戸 洋, 吉田太一, 関野宏, 浅木 茂: 透 析患者と便秘. 透析会誌, 17 (2)；115-121，1984. 